\title{
Review Article \\ Colorful World of Microbes: Carotenoids and Their Applications
}

\author{
Kushwaha Kirti, ${ }^{1}$ Saini Amita, ${ }^{1}$ Saraswat Priti, ${ }^{2}$ \\ Agarwal Mukesh Kumar, ${ }^{2}$ and Saxena Jyoti ${ }^{3}$ \\ ${ }^{1}$ Department of Bioscience and Biotechnology, Banasthali University, Jaipur, Rajasthan 304022, India \\ ${ }^{2}$ Biotechnology Division, Defence Research and Development Establishment, Gwalior, Madhya Pradesh 474012, India \\ ${ }^{3}$ Biochemical Engineering Department, BT Kumaon Institute of Technology, Dwarahat, Uttarakhand 263653, India \\ Correspondence should be addressed to Saxena Jyoti; saxenajyoti30@gmail.com
}

Received 26 January 2014; Revised 2 March 2014; Accepted 4 March 2014; Published 10 April 2014

Academic Editor: Akikazu Sakudo

Copyright (C) 2014 Kushwaha Kirti et al. This is an open access article distributed under the Creative Commons Attribution License, which permits unrestricted use, distribution, and reproduction in any medium, provided the original work is properly cited.

\begin{abstract}
Microbial cells accumulate pigments under certain culture conditions, which have very important industrial applications. Microorganisms can serve as sources of carotenoids, the most widespread group of naturally occurring pigments. More than 750 structurally different yellow, orange, and red colored molecules are found in both eukaryotes and prokaryotes with an estimated market of $\$ 919$ million by 2015. Carotenoids protect cells against photooxidative damage and hence found important applications in environment, food and nutrition, disease control, and as potent antimicrobial agents. In addition to many research advances, this paper reviews concerns with recent evaluations, applications of microbial pigments, and recommendations for future researches with an understanding of evolution and biosynthetic pathways along with other relevant aspects.
\end{abstract}

\section{Introduction}

The human eye does not see in black and white! Color is one of the first characteristics perceived by the human senses. It is integral to the interface between people and nature. Nature is rich in colors obtained from fruits, vegetables, roots, minerals, plants, microalgae, and so forth, and due to their origin from biological material they are often called "biocolors" [1]. Humans have traditionally preferred natural sources to add colors to food, clothing, cosmetics, and medicines. Among the molecules produced by microorganisms are carotenoids, melanins, flavins, phenazines, quinones, and bacteriochlorophylls, and more specifically monascins, violacein, and indigo $[2,3]$.

\section{Pigments from Microbes}

A variety of natural and synthetic pigments are available. Naturally derived pigments are represented by carotenoids, flavonoids (anthocyanins), and some tetrapyrroles (chlorophylls and phycobiliproteins). Lately, interest in synthetically derived pigments has decreased due to their toxic, carcinogenic, and teratogenic properties and attention towards microbial sources has increased as a safe alternative [2, 47]. Several species of algae, fungi, and bacteria have been exploited commercially for the production of pigments $[2,5$, 7].

An inventory ofmicroorganisms producing different pigments is given in Table 1. An ideal pigment producing microorganism should be capable of using a wide range of $\mathrm{C}$ and $\mathrm{N}$ sources, must be tolerant to $\mathrm{pH}$, temperature, and minerals, and must give reasonable color yield. The nontoxic and nonpathogenic nature, coupled with easy separation from cell biomass, are also preferred qualities. Microbial pigments have many advantages over artificial and inorganic colors. One relates this to fermentation, which is an inherently faster and more productive process as compared to other chemical processes. The other enduring strength of microbes is their relatively large and easily manipulated strands of genes. Besides, pigment production from microorganisms is independent of weather conditions, which produce different color shades and grow on cheap substrates [8]. Moreover, 
TABLE 1: List of pigments produced by different microorganisms.

\begin{tabular}{ll}
\hline Pigment & Microorganism \\
\hline Indigoidine (blue-green) & Streptomyces aureofaciens CCM 323, Corynebacterium insidium \\
Carotenoid & Gemmatimonas aurantiaca T-27 \\
Melanin (black-brown) & Kluyveromyces marxianus, Streptomyces chibanensis, Cryptococcus neoformans, \\
& Aspergillus sp., Wangiella dermatitidis, Sporothrix schenckii, and Burkholderia cepacia \\
Prodigiosin (red) & Serratia marcescens, Rugamonas rubra, Streptoverticillium rsubrireticuli, Serratia \\
& rubidaea, Vibrio psychroerythrus, Alteromonas rubra, and Vibrio gaogenes \\
Zeaxanthin & Staphylococcus aureus, Vibrio psychroerythrus, Streptomyces sp., and Hahella \\
Canthaxanthin (orange) & chejuensis \\
Xanthomonadin (yellow) & Monascus roseus, Bradyrhizobium sp. \\
Astaxanthin (red) & Xanthomonas oryzae \\
Violacein (purple) & Phaffia rhodozyma, Haematococcus pulvialis \\
Anthraquinone (red) & Janithobacterium lividum \\
Halorhodopsin and rhodopsin & Pacilmyces farinosus \\
Rosy pink & Halobacterium halobium \\
Violet/purple & Lamprocystis roseopersicina \\
Rosy peach & Thiocystis violacea, Thiodictyon elegans \\
Orange brown & Thiocapsa roseopersicina \\
Pink/Purple violet & Allochromatium vinosum \\
& Allochromatium warmingii \\
\hline
\end{tabular}

pigment production from microbial sources has gained attention owing to public sensitivity regarding "synthetic food additives."

Microbial pigment production can be increased in geometric proportions through genetic engineering, compared to the scaling up methods of chemists. Microbes have also upper hand in versatility and productivity over higher forms of life in the industrial-scale production of natural pigments and dyes. Fermentation process has been increased by genetic engineering and further research for nontoxic microbial pigment can make quantum leaps in the economics of microbial pigments.

2.1. Carotenoid. Carotenoids are a group of pigments of widely distributed classes of structurally and functionally diverse tints from red to yellow present in a wide variety of bacteria, algae, fungi, and plants. They are natural pigments which occur widely in nature and are synthesized by plants and microorganisms in response to various environmental stresses, whereas animals have to obtain them from food [9]. Carotenoids are lipid soluble classes of molecules associated with the lipidic fractions sensitive to oxygen, heat, and light [10]. From a chemical point of view, carotenoids are polyisoprenoid compounds and can be divided into two main groups: (i) carotenes or hydrocarbon carotenoids, which are composed of carbon and hydrogen atoms, and (ii) xanthophylls that are oxygenated hydrocarbon derivatives that contain at least one oxygen function such as hydroxyl, keto, epoxy, methoxy, or carboxylic acid groups.

2.1.1. Nomenclature. Carotenoids have been given trivial names derived from the biological sources from which they were isolated first, which conveyed no information about their structure and, therefore, semisynthetic scheme has been devised to allow any carotenoid to be named unambiguously in a way that defines and describes its structure. All specific names are based on the stem name "carotene" preceded by the Greek letter prefixes that designate the two end groups out of seven $(\psi, \beta, \varepsilon, \gamma, \kappa, \Phi$, and $\chi)$ [19]. The carotenoid pigments most commonly found in nature including the ones of microbial origin belong to the groups given in Table 2 and it is true for microbial carotenoids also. The IUPAC-IUB rules are given in full in an IUPAC publication and in volume $1 \mathrm{~A}$ of the series carotenoids [20].

Some carotenoids have structure consisting of fewer than 40 carbon atoms and derived formally by loss of part of the C40 skeleton. When carbon atoms have been lost from ends of the molecule these compounds are referred to as apocarotenoids or norcarotenoids when carbon atoms have been lost formally from within the chain.

2.1.2. General Properties. In terms of hydrophobicity, carotenoids are a group of extremely hydrophobic molecules with little or no solubility in water which usually do not increase with increase in temperature [21]. In the inner core membranes of the cell, they are expected to be restricted to hydrophobic areas, whereas when associated with proteins they access to an aqueous environment. Polarity of carotenoids is altered by polar functional groups and interaction of carotenoids with other molecules is also affected.

Shape of the carotenoid molecule depends on isomeric forms (trans and cis) and can thus change properties of carotenoid affecting solubility and absorbability. Trans form of carotenoids are more rigid and have a greater tendency to 
TABLE 2: List of naturally produced pigments and their examples.

\begin{tabular}{|c|c|}
\hline Group & Example \\
\hline Hydrocarbons & Lycopersene, Phytofluene, Hexahydrolycopene, Torulene, and $\alpha$-Zeacarotene \\
\hline Alcohols & $\begin{array}{l}\text { Alloxanthin, Cynthiaxanthin, Pectenoxanthin, Cryptomonaxanthin, } \\
\text { Crustaxanthin, Gazaniaxanthin, OH-Chlorobactene, Loroxanthin, } \\
\text { Lycoxanthin, Rhodopin, Rhodopinol aka Warmingol, and Saproxanthin }\end{array}$ \\
\hline Glycosides & Oscillaxanthin, Phleixanthophyll \\
\hline Ether & Rhodovibrin, Spheroidene \\
\hline Epoxides & $\begin{array}{l}\text { Diadinoxanthin, Luteoxanthin, Mutatoxanthin, Citroxanthin, Zeaxanthin } \\
\text { furanoxide, Neochrome, Foliachrome, Trollichrome, and Vaucheriaxanthin }\end{array}$ \\
\hline Aldehydes & Rhodopinal, Wamingone, and Torularhodinaldehyde \\
\hline Acids and esters & Torularhodin, Torularhodin methyl ester \\
\hline Ketones & $\begin{array}{l}\text { Canthaxanthin aka Aphanicin, Chlorellaxanthin, Capsanthin, } \\
\text { Capsorubin, Cryptocapsin, 2,2' Diketospirilloxanthin, Flexixanthin, } \\
\text { Phoenicoxanthin, Hydroxyspheriodenone, Pectenolone, Phoeniconone aka Dehydroadonirubin, } \\
\text { Phoenicopterone, Rubixanthone, and Siphonaxanthin }\end{array}$ \\
\hline Esters of alcohols & $\begin{array}{l}\text { Astacein, Fucoxanthin, Isofucoxanthin, Physalien, Zeaxanthin } \\
\text { dipalmitate, and Siphonein }\end{array}$ \\
\hline Apocarotenoids & $\begin{array}{l}\beta \text {-Apo-2'-carotenal, Apo-2-lycopenal, Apo- } 6 \text {-lycopenal, Azafrinaldehyde, } \\
\text { Bixin, Citranaxanthin, Crocetin, Crocetinsemialdehyde, Crocin Digentiobiosyl, } \\
\text { Hopkinsiaxanthin, Paracentrone, and Sintaxanthin }\end{array}$ \\
\hline Nor or seco carotenoids & $\begin{array}{l}\text { Actinioerythrin, } \beta \text {-Carotenone, Peridinin, Pyrrhoxanthininol, Semi- } \alpha \text {-carotenone, } \\
\text { Semi- } \beta \text {-carotenone, and Triphasiaxanthin }\end{array}$ \\
\hline $\begin{array}{l}\text { Retro carotenoids and } \\
\text { retro apocarotenoids }\end{array}$ & Eschscholtzxanthin, Eschscholtzxanthone, Rhodoxanthin, and Tangeraxanthin \\
\hline Higher carotenoid & Nonaprenoxanthin, Decaprenoxanthin, and Bacterioruberin \\
\hline
\end{tabular}

crystallize or aggregate than cis forms. Acyclic carotenoids (e.g., lycopene) are essentially long, linear molecules with flexible end groups [19]. The overall length of the molecule depends on the effective bulk of the end groups. Cyclization shortens the overall length of the molecule and increases the effective bulk of the end groups and space they occupy. The steric factors and the presence of substituent groups decide the preferred conformation of the effective bulk groups. Oxidation, reduction, hydrogen abstraction, and addition properties of carotenoid molecule are given in detail by Simic [22] and Britton [19]. However, excited state properties of aryl carotenoids have been studied a few years back by femtosecond $\left(10^{-15}\right.$ of a second) transient absorption spectroscopy in important components of light harvesting antennae of green bacteria [23].

The carotenoid have many other independent biological functions, including: specific coloration in plants and animals, screening from excessive light and act as spectral filtering screenings, in some invertebrates they provide defensive action to egg protein against protease; the direct carotenoid derivative-retinal acts as visual pigment in all animals and as chromophore in bacteriorhodopsin photosynthesis, retinoic acid in animals and abscisic acid in plants serve as hormones [24]. Carotenoids are not only useful for coloration but, they have distinctive photochemical properties that form its basis as nutritional components, vitamin A precursors, in the prevention of human diseases such as cancer, and as an industrial perspective. The origin of these photochemical properties lies in the disposition of the low-lying excited energy (both singlet and triplet) of the carotenoids. Beta-carotene protects photosynthetic reaction centre complexes against combination of light and oxygen damage [25] and provides effective treatment for human patients suffering from erythropoietic protoporphyria [26]. Unique arrangement of electronic levels owing to polyene chain structure makes carotenoid the only natural compound that protects the reaction centre from photo damage and is capable of energy transfer from both carotenoid excited state to chlorophyll in the light-harvesting complex and triplet chlorophyll or singlet oxygen to carotenoid in photosynthetic reaction centers [24]. Last section of this review focuses on applications of pigments and carotenoids from microbial origin, while important physical, chemical, and biological properties of carotenoids are compiled in Figure 1.

\subsubsection{Basic Structure}

Conjugated Double and Single Bond. Most striking feature of the carotenoid structure is the long system of alternated double and single bonds that forms the central part of the molecule which constitutes a conjugated system [19]. A conjugated double bond system of a polyene longer than nine is responsible for the pigment properties of carotenoids. Namely, the energy of strong electronic transition [from ground energy level $\left(1 \mathrm{~A}_{\mathrm{g}}{ }^{-}\right)$to the $\mathrm{S} 2$ state $\left.\left(1 \mathrm{~B}_{\mathrm{u}}{ }^{+}\right)\right]$corresponds to the absorption between 400-500 $\mathrm{nm}$ and therefore carotenoids are intensely coloured as yellow, orange or red [19]. The extent of the conjugation and the presence or 


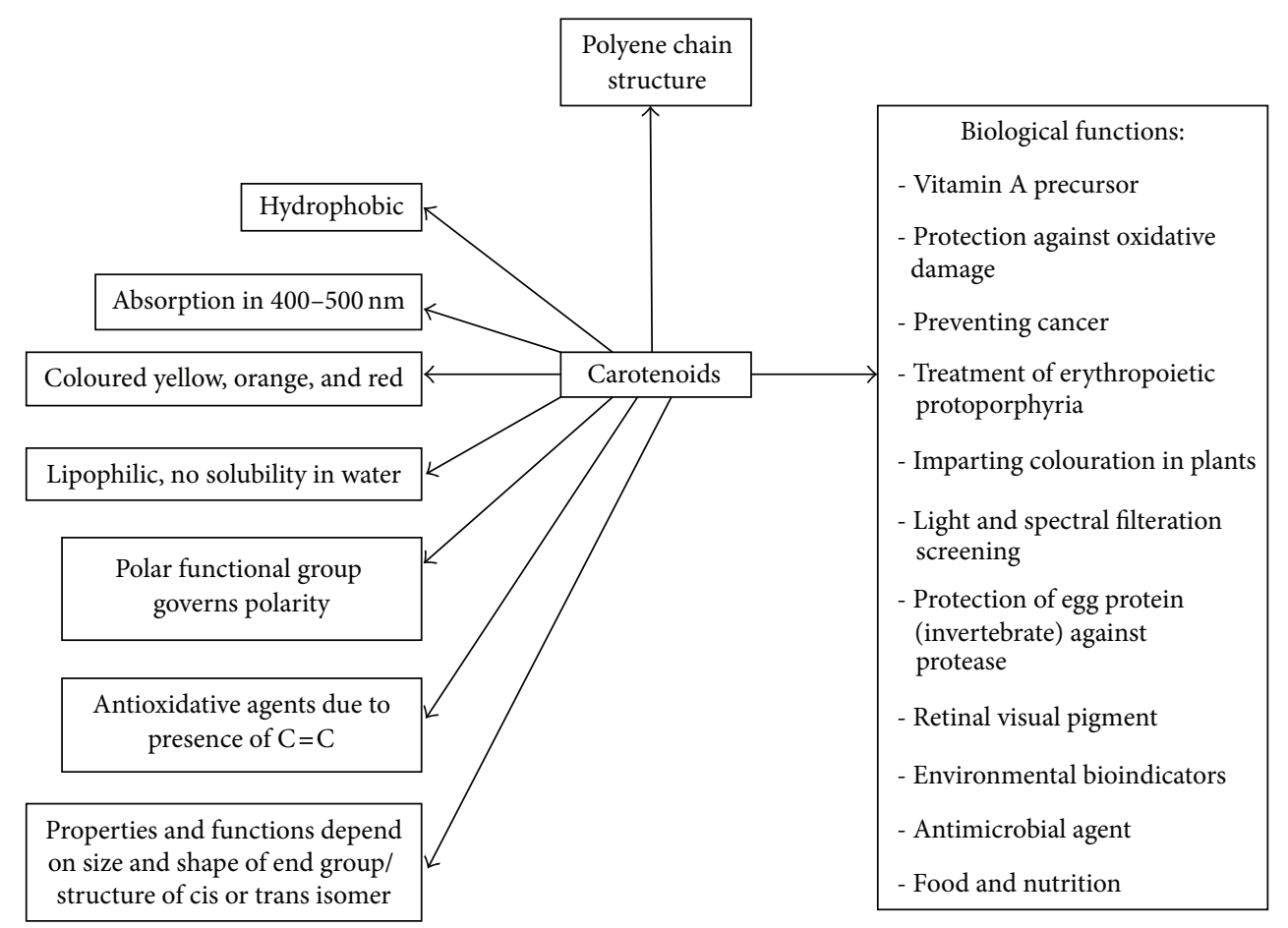

FIGURE 1: Important physical, chemical, and biological properties of carotenoids.

absence of the functions determine the depth of colors of these molecules.

Carotenoids are isoprenoid containing 40 carbon atoms per molecule, variable number of hydrogen atoms, and no other elements. These are biosynthesized by tail to tail linkage of two C-20 geranylgeranyl diphosphate molecules to give the parent C-40 carbon skeleton from which all the individual variations are derived. Termination by hydrocarbon ring, on one or both ends of the molecule, is seen. Since, carotenes are hydrocarbons and therefore contain no oxygen. Lycopene and $\beta, \beta$-carotene can illustrate the basic $\mathrm{C}_{40}$ carbon skeleton structure. The basic structure can be modified by (i) cyclization at one end or both ends of the molecule which gives rise to seven different end groups $(\Psi, \beta, \varepsilon, \gamma, \kappa, \Phi$, and $\chi)$, (ii) the change in hydrogenation level, and (iii) the addition of oxygen containing functional groups to yield a family of more than 750 compounds [19]. Structure and characteristics of some common bacterial pigments are given in Table 3 . The conjugated double bond system constitutes a rigid, rod-like skeleton of carotenoid molecules and provides high reducing potential of carotenoid molecules, which makes them potent antioxidants. The action of carotenoids as antioxidants is importantly evaluated by reactions of carotenoids with oxidizing agents, peroxy radicals, and so forth. This feature seems to play a key role in the stabilization function of carotenoids [27].

All carotenoids possess many conjugated double bonds usually 9-13, with each one being able to form many geometrical isomers. For example, $\beta$-carotene has 9 double bonds in its polyene chain that can freely form cis/trans configurations. Theoretically, it can form 272 isomers, while its asymmetric isomer, $\alpha$-carotene, is capable of forming 512 isomers [28]. Chromophore and light absorption properties are widely used in the identification of carotenoids [29].

2.1.4. Ultrastructural Organization of Carotenoids. The carotenoids must have ability to fit in the correct location and orientation into this complex system. The major features such as overall shape, size, and hydrophobicity determine the ability of a carotenoid to fit into the subcellular structures. The characterization of the individual carotenoid given by structural details then defines the precise orientation that carotenoid can adopt and interact with molecules of its surroundings. Interaction of polar functional group with more polar molecules is focused on in order to allow the carotenoid to participate in events in an aqueous subcellular medium or at an interface or membrane.

Carotenoid molecules interact with themselves and have a significant effect on properties. They are hydrophobic and, hence, show a very strong tendency to aggregate and crystallize in aqueous media. In the form of microcrystalline aggregates carotenoids accumulation is commonly found in chromoplast of higher animals [19].

In membrane, carotenoids are commonly located at an integral part of complex membrane structure [30]. In a variety of microorganisms, orientation and localization of carotenoids in phospholipid liposome bilayer and monolayer influence membrane fluidity, by increasing its rigidity and mechanical strength $[19,31]$. The positioning of carotenoid in the membrane greatly depends on its molecular structure; the hydrocarbon $\beta, \beta$-carotene and lycopene are located in the inner hydrophobic region of the membrane and helps to 
TABLE 3: Structure and characteristics of some common bacterial pigments.

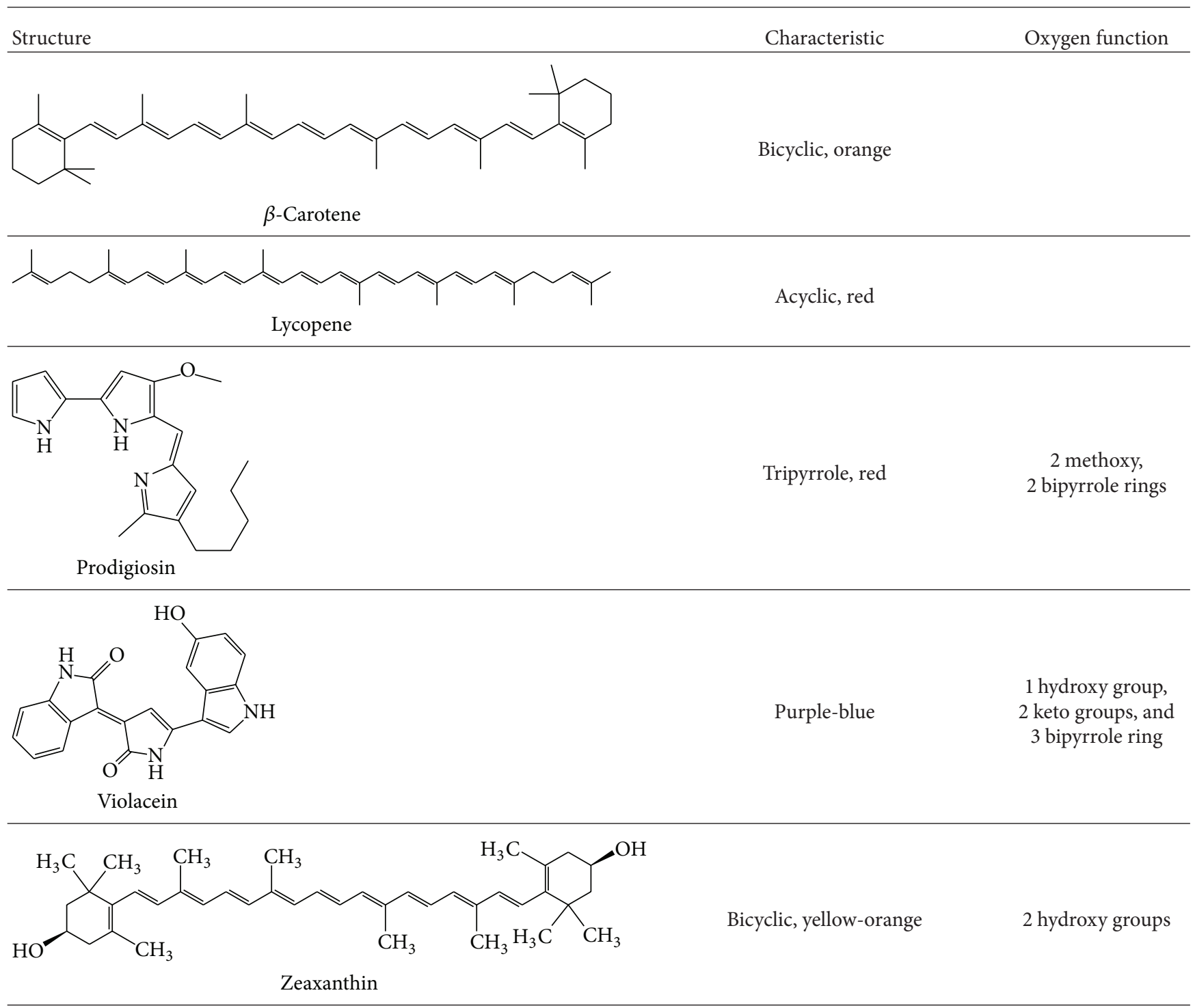<smiles>CC1=C(/C=C/C(C)=C/C=C/C(C)=C/C=C/C=C(C)/C=C/C=C(C)/C=C/C2=C(C)C(=O)[C@@H](O)CC2(C)C)C(C)(C)CC(O)C1=O</smiles><smiles>CC1=C[C@@H](O)CC(C)[C@H]1/C=C/C(C)=C/C=C/C(C)=C/C=C/C=C(C)/C=C/C=C(C)/C=C/C1=C(C)CC(O)CC1(C)C</smiles> 
TABLE 3: Continued.

Structure Characteristic

retain mobility. On the other hand, the diol zeaxanthin may act as a revert. The entire membrane is spanned with its polar end groups which penetrates the surface of the membrane structure and increases its rigidity and mechanical strength; hence, some carotenoids are more effective than others as membrane based protective antioxidants [32].

Role of carotenoids in membrane stabilization has been carried out by C-50 carotenoids with polar end groups as they have correct length for membrane stabilization. C-50 bacterioruberin showed a higher rate of incorporation than the cyclic C-40 carotenoids, particularly when the phospholipid mixture consisted of archaebacterial phytanyl lipids. C-50 carotenoids with polar end groups, such as bacterioruberin, have a molecular length corresponding to the thickness of vesicle lipid bilayers [33]. In Acholeplasma laidlawii mobility restriction was studied by incubating the membrane with phosphatidylcholine vesicles. The carotenoid depleted membrane showed an increase in the mobility of the hydrocarbon chain of the spin labeled fatty acids. Artificial membrane incorporated with carotenoids restricted the mobility of the hydrocarbon chain; hence, it can be inferred that in $A$. laidlawii carotenoids act as a rigid insert which reinforced the membrane bilayer [34]. Psychrotrophic strains of Micrococcus roseus are also shown to produce bacterioruberin, which shows binding affinity with membrane vesicle and interact with $M$. roseus [35].

An experiment at ultrastructural and cytochemical level by Petrunyaka [36] revealed localization of carotenoids in calcium sequestering organelles and their participation in the mechanism of membranous binding and transport of calcium in membrane structure of molluscan neurons.

2.1.5. Carotenoid Protein Interaction. Pigmentation is a common feature of bacteria of different phylogenetic and environmental origins. In general there are several groups of bacterial pigments which are non-covalently bound to proteins such as pigment-protein complexes. These complexes are organized as photosynthetic units, consisting of either photosynthetic reaction centers or light harvesting complexe [37]. Recently in a novel approach Wackerbarth et al. [38] bounded carotenoid

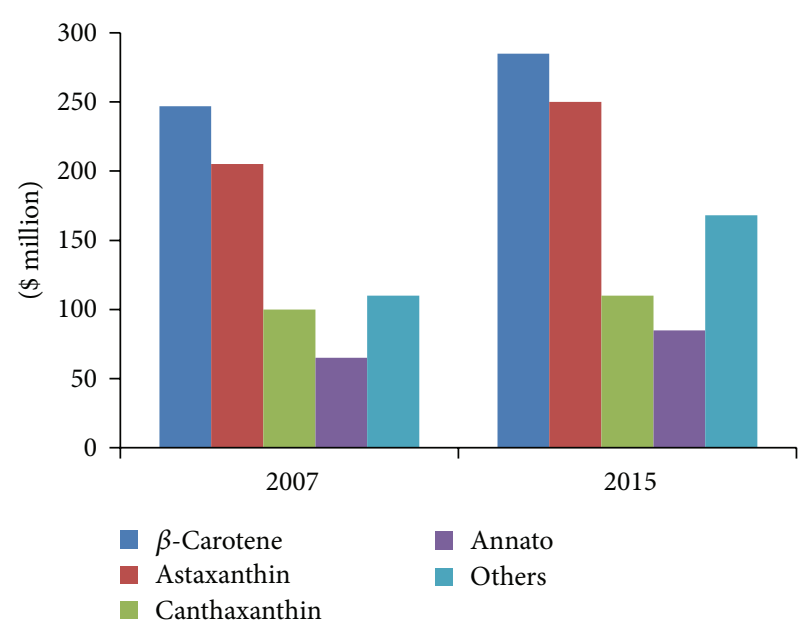

FIGURE 2: Global carotenoid product market in 2007 and 2015 (\$ million): Analyst-Ulrich Marz.

with bovine serum albumin (BSA) and then used carotenoidprotein complex to prepare food emulsions, while Vernon and Augusto [39] studied action of $\alpha$-chymotrypsin on chromatophores of Rhodospirillum rubrum which produced three defined pigment protein complexes, one with brown band and the other two were found in association with bacteriochlorophyll (blue B chl and green B chl).

2.1.6. Production and Biosynthesis of Carotenoids. According to a study the global market for carotenoid was $\$ 766$ million in 2007 and is expected to increase to $\$ 919$ million by 2015 with a compound annual growth rate (CAGR) of $2.3 \%$. $\beta$ Carotene alone shared the market value at $\$ 247$ million in 2007; this segment is expected to be worth $\$ 285$ million by 2015 with CAGR of $1.8 \%$ as shown in Figure 2 [40]. Carotenoids are composed of more than 700 structurally different compounds, typically consist of C-40 hydrocarbon backbone, and often produce cyclic and acyclic xanthophylls by modification with various oxygen containing functional 
groups [41]. Carotenoid biosynthesis is catalyzed by a number of enzymes which fall into few classes based on the type of transformation they catalyze such as geranylgeranyl pyrophosphate synthase, phytoene synthase, carotene desaturase, and lycopene cyclase. Modification of carotenes is further catalyzed by $\beta$-carotene ketolase and $\beta$-carotene hydrolase to generate various C-40 carotenoids. The initial series of steps in the formation of carotenoids belongs to the mevalonate pathway, the general biosynthesis scheme of all isoprenoid compounds. This general isoprenoid biosynthetic pathway which synthesizes carotenoids and other important natural substances in oxygenic photosynthetic (cyanobacteria, algae, and higher plants) and nonphotosynthetic bacteria is been described step by step in detail by many researchers [37, 42-48].

No animal is known to make antioxidants; therefore, scientists thought the only way animals could obtain these through orange-red compounds was from their diet. However, in recent findings, researchers of Arizona University reported that aphids can make their own essential nutrients, called carotenoids, by lateral gene transfer [49].

In environment, where colorful patterns in lakes and soils are found, a variety of bacterial pigments have been found to play important roles. Carotenoids were found in abundance in northern ice shelf microbial mats and exceeded the range of carotenoid concentration reported from Antarctica [50] and in the Arctic including those previously measured in Markham ice shelf [51]. However, the ratio of chlorophyll "a" was higher than carotenoids but not as high as in Antarctica [52] and in nearby Arctic mats [53]. Arctic ice shelf microbial mats contain a broadband pigment assemblage that absorb between the near UV-B to red photosynthetically active radiation (PAR) which is probably beyond the absorption of pigment present in photosynthetic bacteria. These pigments can be classed as screening compounds (OS-MAA'S), light harvesting, and accessory pigments (chlorophylls, phycobiliproteins, certain carotenoids, and perhaps MAA'S). Red color of saltern crystallizer ponds and hypersaline lakes is due to red halophilic archea of the family Halobacteriaceae. Most of the color of the saltern pond may still be attributed to bacterioruberin pigments and the effect is due to the low in vivo optical cross section of the $\beta$-carotene, which is densely packed in granules in the inter thylakoid space within chloroplast polar lipid analysis of biomass (Santa Pola Salterns) shower. Further studies revealed that Salinibacter and other bacteria had minor contribution but halophilic bacteria significantly contributed in the color of ponds [54].

\section{Applications of Microbial Pigments and Carotenoids}

Carotenoids are an important group of natural pigments with specific applications as colorants, food supplements, and nutraceuticals; they are also used for medical, cosmetic, and biotechnological purposes [55].

3.1. Pigments as Bioindicators. Violet pigmented bacteria along with species of Flexibacter and Sporocytophaga were indicators of polluted drinking water samples [56]. Blue pigmented bacteria, Vogesella indigofera, can be used as a bioindicator of chromium contaminated sites. Under normal environmental growth conditions bacterial colonies are pigmented blue, but under metal contaminated growth conditions $\mathrm{Cr}^{6+}$ induces rugosity and inhibits gene expression encoded for blue pigment production as it has been regarded as defensive mechanism performed by bacteria against heavy metal tolerance or environmental stress $[57,58]$. Nianhong et al. [59] used pigments derived from the anoxygenic phototrophic brown bacteria Chlorobium phaeovibroides and C. phaeobacteroides to document the changes in hypoxic event on the Louisiana shelf over the past 100 years.

3.2. Pigments in Food and Nutrition. Early in 1900, a fat soluble principle was explored that was essential for life and was termed as Vitamin A. After a few decades a link between Vitamin A and carotenoids was discovered and later on it was concluded that many of the carotenoids could be metabolized by the body to form Vitamin A. $\beta$-Carotene finds application as solution or suspensions in vegetable oils, in colouring margarine, baked products, and some prepared foods in the form of emulsions or microencapsulated beadlets. It also has applications in beverages such as orange drinks, confectionary, and other prepared foods [60]. In a novel approach, carotenoids were first bound to bovine serum albumin (BSA) and later on this carotenoid-protein complex was used to prepare fortified food emulsions [38]. Table 4 illustrates the microorganisms producing different pigments and their applications in various food industries.

3.3. Pigments in Disease Control and Human Health. In human beings carotenoids as provitamin A can serve as several important functions [61]. Recently, it has been concluded that ingestion of carotene rich yellow and green leafy vegetables improved the total body Vitamin A pool size and hemoglobin concentration subsequently decreased anaemia rates in Fillipino school children, with no effect on iron deficiency [62]. Role of carotenoids on photoprotection against genetic diseases, erythropoietic protoporphyria (EPP) and erythema (skin reddening), has been observed due to photosensitivity associated with quinidine ingestion, which absorb dangerous short wavelength part of light spectrum $[63,64]$.

Premature deaths in the developing nations, particularly amongst children, have been attributed to deficiency of Vitamin A. Vitamin A, which performs many vital functions in human, can be produced within the body from certain carotenoids, particularly $\beta$-carotene $[65,66]$. Lycopene, a hydrocarbon with antioxidant effect, mitigated the damaging effect of oxidation which majorly contributes to the risk of chronic diseases [67] and was found to be effective at quenching the destructive potential of singlet oxygen [68]. Lutein, zeaxanthin, and xanthophyll occur in corn, kale, and spinach and are believed to play a critical role in protection of the age-related macular degeneration (ARMD), the leading cause of blindness in human retina by action as an antioxidant [69]. Astaxanthin has also health benefits in cardiovascular disease prevention, immune system boosting, bioactivity 
TABLE 4: Microbial pigments in food industry.

\begin{tabular}{|c|c|c|}
\hline Microorganism & Pigment & Application in food \\
\hline Xanthophyllomyces dendrorhous & Astaxanthin & $\begin{array}{l}\text { Feed supplement for salmons, crabs, shrimps, chickens, and egg } \\
\text { production }\end{array}$ \\
\hline Ashbya gossypii & Riboflavin & \\
\hline Pseudomonas aeruginosa & & $\begin{array}{l}\text { Colorant in beverages, cakes, confectionaries, pudding, decoration } \\
\text { of food items [11] }\end{array}$ \\
\hline Monascus sp. & Ankaflavin & Color supplement \\
\hline Penicillium oxalicum & Anthraquinone & \\
\hline Fusarium sporotrichioides & Lycopene & \\
\hline Haematococcus pluvialis & Astaxanthin & As animal feed, fish meal \\
\hline Saccharomyces neoformans & Melanin & \\
\hline Monascus sp. & $\begin{array}{l}\text { Monascorubramin } \\
\text { Rubropunctatin }\end{array}$ & \\
\hline Neospongiococcum excentricum & Zeaxanthin & Colorant for poultry and fish \\
\hline Cordyceps unilateralis & Naphtoquinone & \\
\hline Rhodotorula sp. & Torularhodin & \\
\hline Flavobacterium & Zeaxanthin & $\begin{array}{l}\text { As an additive in poultry feed to increase yellow color of animal's } \\
\text { skin and eggyolk [12] } \\
\text { Colorant in cosmetic and food industry }\end{array}$ \\
\hline Bradyrhizobium sp. & Canthaxanthin & Impart color in farmed salmons \\
\hline Halobacterium sp. & Canthaxanthin & {$[13]$} \\
\hline Cantharellus cinnabarinus & Canthaxanthin & Poultry feeds and fish feeds \\
\hline $\begin{array}{l}\text { Brevibacterium KY- } 4313 \\
\text { Rhodococcus maris } \\
\text { (Mycobacterium brevicale) }\end{array}$ & Canthaxanthin & \\
\hline Corynebacterium michiganense & & {$[2]$} \\
\hline Agrobacterium auranticum & Astaxanthin & Food colourant [14] \\
\hline Paracoccus carotinifaciens & Astaxanthin & Food colourant [15] \\
\hline Mycobacterium lacticola & Astaxanthin & Fish feeds \\
\hline $\begin{array}{l}\text { Brevibacterium } 10 \\
\text { Phafja rhodozyma } \\
\text { Peniophora sp. }\end{array}$ & & {$[2]$} \\
\hline Streptomyces echinoruber & Rubrolone & Food colorant \\
\hline Paracoccus zeaxanthinifaciens & Zeaxanthin & Food colorant [16] \\
\hline Flavobacterium sp. & Zeaxanthin & Poultry feed and fish feed [2] \\
\hline Streptomyces coelicolor & Actinorhodin & Edible natural pigment and food colorant [17] \\
\hline $\begin{array}{l}\text { Blakeslea trispora and Dunaliella } \\
\text { salina }\end{array}$ & $\beta$-Carotene & Food colourant [2] \\
\hline Blakeslea trispora & Lycopene & Food colourant \\
\hline Streptomyces chrestomyceticus & & {$[2]$} \\
\hline Spongiococcum excentricum & Lutein & Poultry feeds \\
\hline Chlorella pyrenoidosa & & {$[2]$} \\
\hline Protomonas extorquens & Rhodoxanthin & {$[2]$} \\
\hline
\end{tabular}

against Helicobacter pylori, and cataract prevention due to its high antioxidant activity. The health benefits of astaxanthin in in vitro studies and also in the preclinical trials with humans have mostly been performed in many researches $[2,5,70,71]$.

Other antioxidant carotenoids were used to treat cardiovascular disease (CVD) using membrane enriched with polyunsaturated fatty acids [72], enhancement of immune system function [73], sun burn protection [74], and inhibition of the development of certain types of cancer [75]. Oxidation of low density lipoprotein (LDL) cholesterol and reduction in the risk of development of arteriosclerosis and coronary heart diseases were observed due to lycopene [76]. Carotenoid pigments, present in the eye and photoreceptors, seem especially suited to protect against the deleterious effects 
TABLE 5: Microbial pigments as potential virulence agents [18] (ROS reactive oxygen species).

\begin{tabular}{|c|c|c|c|c|}
\hline Pigment & Chemistry & Color & Human pathogens & Virulence functions \\
\hline Staphyloxanthin & Carotenoid & Golden & Staphylococcus aureus & Antioxidant, detoxify ROS \\
\hline Pyocyanin & $\begin{array}{c}\text { Phenazine derived } \\
\text { Zwitterion }\end{array}$ & $\begin{array}{c}\text { Blue } \\
\text { green }\end{array}$ & Pseudomonas sp. & $\begin{array}{l}\text { Cytotoxicity, neutrophil apoptosis, } \\
\text { ciliary dysmotility, proinflammatory }\end{array}$ \\
\hline Melanin & $\begin{array}{l}\text { Polyacetylene or } \\
\text { polypyrrole polymers }\end{array}$ & $\begin{array}{l}\text { Dark-brown, } \\
\text { black }\end{array}$ & $\begin{array}{c}\text { Cryptococcus neoformans, } \\
\text { Wangiella dermatitidis, } \\
\text { Sporothrix schenckii, } \\
\text { Sporothrix schenckii, } \\
\text { Aspergillus sp. }\end{array}$ & $\begin{array}{c}\text { Antioxidants } \\
\text { Antiphagocytic } \\
\text { Block antimicrobials }\end{array}$ \\
\hline Porphyrin & Heteromacrocycle & Black & Porphyromonas gingivalis & Antioxidant, detoxify ROS \\
\hline Granadaene & $\begin{array}{l}\text { Ornithine } \\
\text { rhamno-polyene }\end{array}$ & $\begin{array}{l}\text { Orange } \\
\text { red }\end{array}$ & Streptococcus agalactiae & Antioxidant, detoxify ROS \\
\hline Violacein & $\begin{array}{c}\text { Rearranged } \\
\text { pyrrolidone scaffold }\end{array}$ & Purple & $\begin{array}{c}\text { Chromobacterium } \\
\text { violaceum }\end{array}$ & Antioxidant, detoxify ROS \\
\hline Prodigiosin & Linear tripyrrole & Red & Serratia marcescens & Immunosuppressant \\
\hline Hemozoin & $\beta$-hematin aggregates & Brown-black & Plasmodium sp. & $\begin{array}{c}\text { Detoxification, macrophage suppression, } \\
\text { proinflammatory }\end{array}$ \\
\hline
\end{tabular}

of light because of their capability to absorb the dangerous short wavelength of the light spectrum. Carotenoids are well known for "quenching" in plant tissues and photoexcitation of sensitizing pigments and oxygen in animal tissues [64]. Prodigiosin from Serratia marcescens is the pigment of high medical importance as its anticancerous activity on HeLa cell lines was reported by Campàs et al. [77]. Earlier, many other medically important activities of prodigiosin have also been reported such as in lymphocytic leukemia, apoptosis in gastric (HGT-1) cancer cell lines, apoptosis in haematopoietic cancer cell line [78], cytotoxic sensitivity of the human small cell lung doxorubicin resistant carcinoma (GLC4/ADR) cell lines [79], synergistic inhibitory activity against spore germination of Botrytis cinerea [80], and selective activity against cancer cell lines [81]. Prodigiosin from Serratia marcescens [82], Vibrio psychroerythrous [83], and Pseudomonas magneslorubra also have been reported as antifungal, immunosuppressive, and antiproliferative agents in early days of 1970 s.

Data has been collected regarding the efficacy of various carotenoids in prevention of diseases in combination with other therapies [84-90]. A leading hypothesis in mechanism of action of carotenoids is that they serve as singlet oxygen quenchers and antioxidants; a group of large number of dietary and endogenous components functions as antioxidants in preventing free radical damage to critical cellular components as carotenoids do not act alone [91].

3.4. Pigments and the Immune System. Role of carotenoids in modulating immunological reactions has been noticed by several workers. The pigments enhanced both specific and nonspecific immune functions and showed the capability to enhance tumor immunity. Postulates have been given for role of carotenoids in enhancing immune activity by (i) quenching excessive reactive species formed by various immunoactive cells, (ii) quenching immunosuppressive peroxides and maintaining membrane fluidity, (iii) helping to maintain membrane receptors essential for immune functions and (iv) acting in the release of immunomodulatory lipid molecules such as prostaglandins and leukotrienes [92]. Color of colonies is a hallmark feature of several pathogenic microbes. By interfering with host immune clearance mechanisms or by exhibiting proinflammatory or cytotoxic properties the microbial pigment sometimes contributes to disease pathogenesis. Contribution of pigmentation in virulence by allowing a given microbe to evade host immunity by killing or provoking inflammatory damage to cells and tissues is given in Table 5 [18].

3.5. Pigments as Antimicrobial Agents. Nature is rich in colors (minerals, plants, microalgae, etc.) and pigment producing microorganisms (fungi, yeast, and bacteria). As stated in introduction among the molecules produced by microorganisms (carotenoids, melanins, flavins, and quinones, and, more specifically, monascins, violacein, and indigo); pyocyanin and pyorubin pigments of Pseudomonas aeruginosa showed distinct antibacterial effect against Citrobacter sp., a member of the family Enterobacteriace, which causes urinary tract infections, wound infections, and sometimes pneumonia in humans especially in immunocompromised persons [11]. Seven carotenoids, namely, (all-E)-luteoxanthin, (all-E)neoxanthin, (9' Z)-neoxanthin, (all-E)-antheraxanthin, (allE)-violaxanthin, (9'Z)-violaxanthin, and (all-E)-lutein, were isolated from golden delicious apple and showed potent anti-Helicobacter pylori activity $\left(\mathrm{CMIC}_{50}=36 \mu \mathrm{g} / \mathrm{mL}\right)$ [93]. An actinomycete strain, Streptomyces hygroscopicus subsp. ossamyceticus $\mathrm{D}_{10}$, produced a yellow color sugar containing pigment with antimicrobial activity against drug resistant pathogens such as methicillin resistant and vancomycin resistant strains of Staphylococcus aureus, $\beta$-lactamase producing culture of E. coli, Pseudomonas aeruginosa, and Klebsiella sp. [94]. Similarly, a yellowish pigment 4-hydroxynitrobenzene from Streptomyces species was isolated which later showed antibiotic activity against Bacillus subtilis and Shigella shiga 
[95]. Hydrophobic amino acid derivatives (L-Tyr and L-Phe) from monascins exhibited antimicrobial activity against $E$. coli [96]. Inhibition of human pathogenic bacteria, Staphylococcus aureus, Klebsiella pneumoniae, and Vibrio cholera, was observed by endophytic fungal pigment of Monodictys castaneae [97].

\section{Questions to Be Answered and Future Outlook}

Steps are being taken towards understanding the unfamiliar world of microbes, but there are still many questions to be explored and currently exist as unanswered. The spectra of compounds that are potentially diverse in function are generated by pigment biosynthetic pathways. The functions and the regulation of synthesis of specific product subsets under different environmental conditions are another area waiting to be investigated. A large number of catalytic steps and metabolic expenditure are involved in biosynthetic pathways and hence pigments are very important. The other questions which often arise are as follows: How do microbial cells put together complex pigment biosynthetic pathways and what are evolutionary processes shape assembly of the final pathway? How can pigment properties and biosynthetic pathways be exploited for drug discovery and other important applications for engineering of novel agents?

The understanding of structure-function relationships will enable researchers to tailor new bacterial pigments for biotechnological applications. Due to the high cost of the currently used technology for the microbial pigment production on an industrial scale, there is a need for developing low cost process for the production of the pigments that could replace the synthetic ones. Developments in research is expected from interchange of experiences between biochemists, geneticists, biochemical engineers, and so forth. Colorful bacteria represent an extremely versatile group of microorganisms capable of a variety of important applications, thereby presenting a fascinating field for future research.

\section{Conflict of Interests}

The authors declare that there is no conflict of interests regarding the publication of this paper.

\section{References}

[1] P. Pattnaik, U. Roy, and P. Jain, "Biocolours: new generation additives for food," Indian Food Industry, vol. 16, no. 5, pp. 21-32, 1997.

[2] H. J. Nelis and A. P. de Leenheer, "Microbial sources of carotenoid pigments used in foods and feeds," Journal of Applied Bacteriology, vol. 70, no. 3, pp. 181-191, 1991.

[3] L. Dufosse, "Pigments," Encyclopedia of Microbiology, vol. 4, pp. 457-471, 2009.

[4] S. Babu and I. S. Shenolikar, "Health and nutritional implications of food colours," Indian Journal of Medical Research, vol. 102, pp. 245-249, 1995.
[5] E. A. Johnson and W. A. Schroeder, "Microbial carotenoids," Advances in biochemical engineering/biotechnology, vol. 53, pp. 119-178, 1996.

[6] V. R. O. Canizares, L. E. Rios, R. R. Olvera, N. T. Ponce, and R. F. Marquez, "Microbial sources of pigments," Revista Latinoamericana de Microbiología, vol. 40, no. 1-2, pp. 87-107, 1998.

[7] S. Babitha, Biotechnology for Agro-Industrial. Residues Utilization II, Microbial Pigments, 2009.

[8] V. K. Joshi, D. Attri, A. Bala, and S. Bhushan, "Microbial pigments," Indian Journal of Biotechnology, vol. 2, no. 3, pp. 362369, 2003.

[9] H. Klaui, "Industrial and commercial uses of carotenoids," in IUPAC Carotenoid Chemistry and BioChemistry, G. Britton and T. W. Goodwin, Eds., pp. 309-317, Pergamon Press, Oxford, UK, 1982.

[10] I. H. Ciapara, L. F. Valenzuela, F. M. Goycoolea, and W. A. Monal, "Microencapsulation of astaxanthin in a chitosan matrix," Carbohydrate Polymers, vol. 56, no. 1, pp. 41-45, 2004.

[11] S. Saha, R. Thavasi, and S. Jayalakshmi, "Phenazine pigments from Pseudomonas aeruginosa and their application as antibacterial agent and food colourants," Research Journal of Microbiology, vol. 3, no. 3, pp. 122-128, 2008.

[12] S. Alcantara and S. Sanchez, "Influence of carbon and nitrogen sources on Flavobacterium growth and zeaxanthin biosynthesis," Journal of Industrial Microbiology and Biotechnology, vol. 23, no. 1, pp. 697-700, 1999.

[13] J. Lorquin, F. Molouba, and B. L. Dreyfus, "Identification of the carotenoid pigment canthaxanthin from photosynthetic Bradyrhizobium strains," Applied and Environmental Microbiology, vol. 63, no. 3, pp. 1151-1154, 1997.

[14] A. Yokoyama, H. Izumida, and W. Miki, "Production of astaxanthin and 4-ketozeaxanthin by the marine bacterium, Agrobacterium aurantiacum," Bioscience, Biotechnology and Biochemistry, vol. 58, no. 10, pp. 1842-1844, 1994.

[15] A. Tsubokura, H. Yoneda, and H. Mizuta, "Paracoccus carotinifaciens sp. nov., a new aerobic Gram-negative astaxanthinproducing bacterium," International Journal of Systematic Bacteriology, vol. 49, no. 1, pp. 277-282, 1999.

[16] M. Hümbelin, A. Thomas, J. Lin, J. Li, J. Jore, and A. Berry, "Genetics of isoprenoid biosynthesis in Paracoccus zeaxanthinifaciens," Gene, vol. 297, no. 1-2, pp. 129-139, 2002.

[17] H. C. Zhang, J. X. Zhan, K. M. Su, and Y. X. Zhang, "A kind of potential food additive produced by Streptomyces coelicolor: characteristics of blue pigment and identification of a novel compound, $\lambda$-actinorhodin," Food Chemistry, vol. 95, no. 2, pp. $186-192,2006$

[18] G. Y. Liu and V. Nizet, "Color me bad: microbial pigments as virulence factors," Trends in Microbiology, vol. 17, no. 9, pp. 406413, 2009.

[19] G. Britton, "Structure and properties of carotenoids in relation to function," The FASEB Journal, vol. 9, no. 15, pp. 1551-1558, 1995.

[20] "IUPAC commission on the nomenclature of organic chemistry and IUPAC-IUB commission on biochemical nomenclature, nomenclature of carotenoids (Rules approved 1974)," Pure and Applied Chemistry, vol. 41, pp. 407-431, 1975.

[21] A. Wisniewska and W. K. Subczynski, "Effects of polar carotenoids on the shape of the hydrophobic barrier of phospholipid bilayers," Biochimica et Biophysica Acta, vol. 1368, no. 2, pp. 235-246, 1998. 
[22] M. G. Simic, "Carotenoid free radicals," Methods in Enzymology, vol. 213, pp. 444-453, 1992.

[23] M. Fuciman, P. Chabera, A. Zupcanova et al., "Excited state properties of aryl Carotenoids," Physical Chemistry Chemical Physics, vol. 12, no. 3, pp. 3112-3120, 2010.

[24] A. Vershinin, "Biological functions of Carotenoids-diversity and evolution," BioFactors, vol. 10, no. 2-3, pp. 99-104, 1999.

[25] H. A. Frank and R. J. Cogdell, "The photochemistry and functions of carotenoids in photosynthesis," in Carotenoids in Photosynthesis, A. Young and G. Britton, Eds., pp. 252-326, Springer, London, UK, 1993.

[26] M. M. Mathews-Roth, "Medical application and uses of Carotenoids," in Carotenoid-Chemistry and Boichemistry IUPAC, G. Britton and T. W. Goodwin, Eds., pp. 297-307, Pergamon Press, Oxford, UK, 1982.

[27] W. I. Gruszecki and K. Strzałka, "Carotenoids as modulators of lipid membrane physical properties," Biochimica et Biophysica Acta, vol. 1740, no. 2, pp. 108-115, 2005.

[28] J. A. Olson and N. I. Krinsky, "Introduction: the colorful, fascinating world of the carotenoids: important physiologic modulators," The FASEB Journal, vol. 9, no. 15, pp. 1547-1550, 1995.

[29] G. Britton, "UV/Visible spectroscopy," in Spectroscopy $1 B$, G. Britton, J. S. Liaanen, and H. Pfander, Eds., pp. 13-62, Birkhäuser, Basel, Switzerland, 1995.

[30] W. I. Gruszecki and J. Sielewiesiuk, "Orientation of xanthophylls in phosphatidylcholine multibilayers," Biochimica et Biophysica Acta, vol. 1023, no. 3, pp. 405-412, 1990.

[31] G. A. Armstrong, "Genetics of eubacterial carotenoid biosynthesis: a colorful tale," Annual Review of Microbiology, vol. 51, pp. 629-659, 1997.

[32] N. J. C. Fong, M. L. Burgess, K. D. Barrow, and D. R. Glenn, "Carotenoid accumulation in the psychrotrophic bacterium Arthrobacter agilis in response to thermal and salt stress," Applied Microbiology and Biotechnology, vol. 56, no. 5-6, pp. 750-756, 2001.

[33] G. Ourisson and Y. Nakatani, "Bacterial Carotenoids as membrane reinforcers: a general role of polyterpenoids: membrane stabilization," in Carotenoids: Chemistry and Biochemistry, N. I. Krinsky, M. M. Mathew-Roth, and R. F. Taylor, Eds., pp. 237245, Plenum Press, New York, NY, USA, 1989.

[34] S. Rottem and O. Markowitz, "Carotenoids act as reinforcers of the Acholeplasma laidlawii lipid bilayer," Journal of Bacteriology, vol. 140, no. 3, pp. 944-948, 1979.

[35] M. V. Jagannadham, K. Narayanan, C. Mohan Rao, and S. Shivaji, "In vivo characteristics and localisation of carotenoid pigments in psychrotrophic and mesophilic Micrococcus roseus using photoacoustic spectroscopy," Biochemical and Biophysical Research Communications, vol. 227, no. 1, pp. 221-226, 1996.

[36] V. V. Petrunyaka, "Localization and role of carotenoids in molluscan neurons," Cellular and Molecular Neurobiology, vol. 2, no. 1, pp. 11-20, 1982.

[37] R. J. Cogdell, P. Fyfe, N. Fraser et al., "Photosynthetic light harvesting," in Microbial Responses to Light and Time, M. X. Caddick, S. Baumberg, D. A. Hodgson, and M. K. Phillips Jones, Eds., pp. 143-158, SGM symposium, Cambridge University Press, Cambridge, UK, 1998.

[38] H. Wackerbarth, T. Stoll, S. Gebken, C. Pelters, and U. Bindrich, "Carotenoid-protein interaction as an approach for the formulation of functional food emulsions," Food Research International, vol. 42, no. 9, pp. 1254-1258, 2009.
[39] L. P. Vernon and F. G. Augusto, "Pigment protein complexes derived from Rhodospirillum rubrum chromatophores by enzymatic digestion," Biochimica et Biophysica Acta, vol. 143, no. 1, pp. 144-153, 2003.

[40] report code: FOD025C, 2008 http://www.bccresearch.com/ report/FOD025C.html.

[41] G. A. Armstrong, "Eubacteria show their true colors: genetics of carotenoid pigment biosynthesis from microbes to plants," Journal of Bacteriology, vol. 176, no. 16, pp. 4795-4802, 1994.

[42] S. Pandian, S. Saengchjan, and T. S. Raman, "An alternative pathway for the biosynthesis of isoprenoid compounds in bacteria," Biochemical Journal, vol. 196, no. 3, pp. 675-681, 1981.

[43] M. S. Anderson, J. G. Yarger, C. L. Burck, and C. D. Poulter, "Farnesyl diphosphate synthetase. Molecular cloning, sequence, and expression of an essential gene from Saccharomyces cerevisiae," Journal of Biological Chemistry, vol. 264, no. 32, pp. 19176-19184, 1989.

[44] Y. Tani, "Microbial production of vitamin B6 and derivatives," in Biotechnology of Vitamins, Pigments and Growth Factors, E. J. Vandamme, Ed., pp. 221-230, Elsevier, London, UK, 1989.

[45] S. Fujisaki, H. Hara, Y. Nishimura, K. Horiuchi, and T. Nishino, "Cloning and nucleotide sequence of the ispA gene responsible for farnesyl diphosphate synthase activity in Escherichia coli," Journal of Biochemistry, vol. 108, no. 6, pp. 995-1000, 1990.

[46] J. Schwender, M. Seemann, H. K. Lichtenthaler, and M. Rohmer, "Biosynthesis of isoprenoids (carotenoids, sterols, prenyl sidechains of chlorophylls and plastoquinone) via a novel pyruvate/glyceraldehyde 3-phosphate non-mevalonate pathway in the green alga Scenedesmus obliquus," Biochemical Journal, vol. 316, no. 1, pp. 73-80, 1996.

[47] D. Umeno, A. V. Tobias, and F. H. Arnold, "Diversifying carotenoid biosynthetic pathways by directed evolution," Microbiology and Molecular Biology Reviews, vol. 69, no. 1, pp. 51-78, 2005.

[48] C. Liang, F. Zhao, W. Wei, Z. Wen, and S. Qin, "Carotenoid biosynthesis in cyanobacteria: structural and evolutionary scenarios based on comparative genomics," International Journal of Biological Sciences, vol. 2, no. 4, pp. 197-207, 2006.

[49] N. A. Moran and T. Jarvik, "Lateral transfer of genes from fungi underlies carotenoid production in aphids," Science, vol. 328, no. 5978, pp. 624-627, 2010.

[50] W. F. Vincent, M. T. Downes, R. W. Castenholz, and C. HowardWilliams, "Community structure and pigment organisation of cyanobacteria-dominated microbial mats in Antarctica," European Journal of Phycology, vol. 28, no. 4, pp. 213-221, 1993.

[51] W. F. Vincent, D. R. Mueller, and S. Bonilla, "Ecosystems on ice: the microbial ecology of Markham Ice Shelf in the high Arctic," Cryobiology, vol. 48, no. 2, pp. 108-112, 2004.

[52] K. Sabbe, D. A. Hodgson, E. Verleyen et al., "Salinity, depth and the structure and composition of microbial mats in continental Antarctic lakes," Freshwater Biology, vol. 49, no. 3, pp. 296-319, 2004.

[53] D. R. Mueller, W. F. Vincent, S. Bonilla, and I. Laurion, "Extremotrophs, extremophiles and broadband pigmentation strategies in a high arctic ice shelf ecosystem," FEMS Microbiology Ecology, vol. 53, no. 1, pp. 73-87, 2005.

[54] A. Oren and F. Rodriguez-Valera, "The contribution of halophilic Bacteria to the red coloration of saltern crystallizer ponds," FEMS Microbiology Ecology, vol. 36, no. 2-3, pp. 123130, 2001. 
[55] J. F. Martin, E. Gudina, and J. Barredo, "Conversion of $\beta$ carotene into astaxanthin: two separate enzymes or a bifunctional hydroxylase-ketolase protein," Microbial Cell Factories, vol. 7, no. 3, pp. 1475-2859, 2008.

[56] P. R. G. Schindler and H. Metz, "Bacteria of the Flexibacter Sporocytophaga group and violet-colored bacteria as indicators of hygienic hazardous drinking water," Zentralblatt fur Hygiene und Umweltmedizin, vol. 189, no. 1, pp. 29-36, 1989.

[57] J.-D. Gu and K. H. Cheung, "Phenotypic expression of Vogesella indigofera upon exposure to hexavalent chromium, $\mathrm{Cr}^{6+}$," World Journal of Microbiology and Biotechnology, vol. 17, no. 5, pp. 475480, 2001.

[58] Z. Vanessa and C. Cardona, Molecular analysis, physiological study and biotechnological capabilities of blue pigmented bacteria from Puerto Rico [Ph.D. dissertation], University of Puerto Rico, 2010.

[59] C. Nianhong, T. S. Bianchi, B. A. McKee, and J. M. Bland, "Historical trends of hypoxia on the Louisiana shelf: application of pigment as biomarkers," Organic Geochemistry, vol. 32, no. 4, pp. 543-561, 2001.

[60] E. J. Vandamme, "Biotechnology of Vitamins, Pigments of growth factors," in Applied Sciences, E. J. Vandamme, Ed., pp. 15-21, Elsevier Science Publishers, London, UK, 1989.

[61] A. Zeb and S. Mehmood, "Carotenoids content from various sources and their potential health applications," Pakistan Journal of Nutrition, vol. 3, no. 3, pp. 199-204, 2004.

[62] C. C. Maramag, J. D. Ribaya-Mercado, P. Rayco-Solon et al., "Influence of carotene-rich vegetable meals on the prevalence of anaemia and iron deficiency in Filipino school children," European Journal of Clinical Nutrition, vol. 64, no. 5, pp. 468474, 2010.

[63] A. Kornhauser, W. Wamer, and L. Lambert, in Carotenoids: Chemistry and Biology, N. I. Krinsky, M. M. Mathews-Roth, and R. F. Taylor, Eds., pp. 301-312, Plenum Press, New York, NY, USA, 1990.

[64] K. Ibrahim, T. J. Hassan, and S. N. Jafarey, "Plasma vitamin A and carotene in maternal and cord blood," Asia-Oceania Journal of Obstetrics and Gynaecology, vol. 17, no. 2, pp. 159-164, 1991.

[65] S. Patton, L. M. Canfield, G. E. Huston, A. M. Ferris, and R. G. Jensen, "Carotenoids of human colostrum," Lipids, vol. 25, no. 3, pp. 159-165, 1990.

[66] A. V. Rao and L. G. Rao, "Carotenoids and human health," Pharmacological Research, vol. 55, no. 3, pp. 207-216, 2007.

[67] P. Di Mascio, S. Kaiser, and H. Sies, "Lycopene as the most efficient biological carotenoid singlet oxygen quencher," Archives of Biochemistry and Biophysics, vol. 274, no. 2, pp. 532-538, 1989.

[68] D. M. Snodderly, "Evidence for protection against age-related macular degeneration by carotenoids and antioxidant vitamins," American Journal of Clinical Nutrition, vol. 62, no. 6, pp. 1448S-14615S, 1995.

[69] M. G. Sajilata, R. S. Singhal, and M. Y. Kamat, "The carotenoid pigment zeaxanthin-a review," Comprehensive Reviews in Food Science and Food Safety, vol. 7, no. 1, pp. 29-49, 2008.

[70] P. Bhosale, "Environmental and cultural stimulants in the production of carotenoids from microorganisms," Applied Microbiology and Biotechnology, vol. 63, no. 4, pp. 351-361, 2004.

[71] H. McNulty, R. F. Jacob, and R. P. Mason, "Biological activity of Carotenoids related to distinct membrane physiochemical interactions," American Journal of Cardiology, vol. 101, no. 10, pp. 20D-29D, 2008.
[72] A. Bendich, "Carotenoids and the immune response," Journal of Nutrition, vol. 119, no. 1, pp. 112-115, 1989.

[73] M. M. Mathews-Roth, "Plasma concentrations of carotenoids after large doses of $\beta$-carotene," American Journal of Clinical Nutrition, vol. 52, no. 3, pp. 500-501, 1990.

[74] H. Nishino, "Cancer prevention by carotenoids," Mutation Research, vol. 402, no. 1-2, pp. 159-163, 1998.

[75] S. Agarwal and A. V. Rao, "Tomato lycopene and low density lipoprotein oxidation: a human dietary intervention study," Lipids, vol. 33, no. 10, pp. 981-984, 1998.

[76] N. V. Raj, D. Dhanashekaran, T. Nooruddin, and A. Panneerselvam, "Production of prodigiosin from Serratia marescens and its cytotoxicity activity," Journal of Pharmacy Research, vol. 2, no. 4, pp. 590-593, 2009.

[77] C. Campàs, M. Dalmau, B. Montaner et al., "Prodigiosin induces apoptosis of B and T cells from B-cell chronic lymphocytic leukemia," Leukemia, vol. 17, no. 4, pp. 746-750, 2003.

[78] B. Montaner, S. Navarro, M. Piqué et al., "Prodigiosin from the supernatant of Serratia marcescens induces apoptosis in haematopoietic cancer cell lines," British Journal of Pharmacology, vol. 131, no. 3, pp. 585-593, 2000.

[79] E. Llagostera, V. Soto-Cerrato, R. Joshi, B. Montaner, P. Gimenez-Bonafé, and R. Pérez-Tomás, "High cytotoxic sensitivity of the human small cell lung doxorubicin-resistant carcinoma (GLC4/ADR) cell line to prodigiosin through apoptosis activation," Anti-Cancer Drugs, vol. 16, no. 4, pp. 393-399, 2005.

[80] S. Nobutaka, N. Masami, H. Kazayuki, H. Tadaaki, and M. Katsumi, "Synergistic antifungal activity of chitinolytic enzymes and prodigiosin produced by biocontrol bacterium: serratia marescens strain B2 against gray mold pathogen: Botyritis cinerea," Journal of General Plant Pathology, vol. 67, no. 4, pp. 312-319, 2001.

[81] R. A. Manderville, "Synthesis, proton-affinity and anti-cancer properties of the prodigiosin-group natural products," Current Medicinal Chemistry-Anti-Cancer Agents, vol. 1, no. 2, pp. 195218, 2001.

[82] A. V. Giri, N. Anandkumar, G. Muthukumaran, and G. Pennathur, "A novel medium for the enhanced cell growth and production of prodigiosin from Serratia marcescens isolated from soil," BMC Microbiology, vol. 4, pp. 1-10, 2004.

[83] D. K. Paruchuri and R. M. Harshey, "Flagellar variation in Serratia marcescens is associated with color variation," Journal of Bacteriology, vol. 169, no. 1, pp. 61-65, 1987.

[84] Q.-J. Lu, C.-Y. Huang, S.-X. Yao, R.-S. Wang, and W. U. Xiao$\mathrm{Na}$, "Effects of fat soluble extracts from vegetable powder and beta-carotene on proliferation and apoptosis of lung cancer cell. YTMLC-90," Biomedical and Environmental Sciences, vol. 16, no. 3, pp. 237-245, 2003.

[85] D. D. Karp, A. S. Tsao, and E. S. Kim, "Nonsmall-cell lung cancer: chemoprevention studies," Seminars in Thoracic and Cardiovascular Surgery, vol. 15, no. 4, pp. 405-420, 2003.

[86] N. van Zandwijk and F. R. Hirsch, "Chemoprevention of lung cancer. Current status and future prospects," Lung Cancer, vol. 42, no. 2, pp. S71-S79, 2003.

[87] R. M. Russell, "The enigma of $\beta$-carotene in carcinogenesis: what can be learned from animal studies," Journal of Nutrition, vol. 134, no. 1, pp. 262S-268S, 2004.

[88] A. R. Kristal, "Vitamin A, Retionoids and Carotenoids as chemo preventive agents for prostrate cancer," Journal Of Urology, vol. 171, no. 2, pp. 54-58, 2004. 
[89] M. A. Murtaugh, K.-N. Ma, J. Benson, K. Curtin, B. Caan, and M. L. Slattery, "Antioxidants, Carotenoids and risk of rectal cancer," American Journal of Epidemiology, vol. 159, no. 1, pp. 32-41, 2004.

[90] S. Männistö, S. A. Smith-Warner, D. Spiegelman et al., "Dietary carotenoids and risk of lung cancer in a pooled analysis of seven cohort studies," Cancer Epidemiology Biomarkers and Prevention, vol. 13, no. 1, pp. 40-48, 2004.

[91] N. I. Krinsky, "Mechanism of action of biological antioxidants," Proceedings of the Society for Experimental Biology and Medicine, vol. 200, no. 2, pp. 248-254, 1992.

[92] A. Bendich, "Carotenoids and the immune system," in Carotenoids: Chemisrty and Biology, N. I. Krinsky, M. M. Mathews-Roth, and R. F. Taylor, Eds., pp. 323-336, Plenum Press, NewYork, NY, USA, 1990.

[93] P. Molnár, J. Deli, T. Tanaka et al., "Carotenoids with antiHelicobacter pylori activity from Golden delicious apple," Phytotherapy Research, vol. 24, no. 5, pp. 644-648, 2010.

[94] L. Selvameenal, M. Radhakrishnan, and R. Balagurunathan, "Antibiotic pigment from desert soil actinomycetes; Biological activity, purification and chemical screening," Indian Journal of Pharmaceutical Sciences, vol. 71, no. 5, pp. 499-504, 2009.

[95] Z. S. Sathi, N. Sugimoto, M. I. Khali, and M. A. Gafur, "Isolation of yellowish antibiotic pigment 4-hydroxy Nitrobenzene from a strain of Streptomyces," Pakistan Journal of Biological Sciences, vol. 52, pp. 201-203, 2002.

[96] C. Kim, H. Jung, J. H. Kim, and C. S. Shin, "Effect of monascus pigment derivatives on the electrophoretic mobility of bacteria, and the cell adsorption and antibacterial activities of pigments," Colloids and Surfaces B, vol. 47, no. 2, pp. 153-159, 2006.

[97] S. Visalakchi and J. Muthumary, "Antimicrobial activity of the new endophytic Monodictys castaneae SVJM139 pigment and its optimization," African Journal of Microbiology Research, vol. 4, no. 1 , pp. $38-44,2010$. 

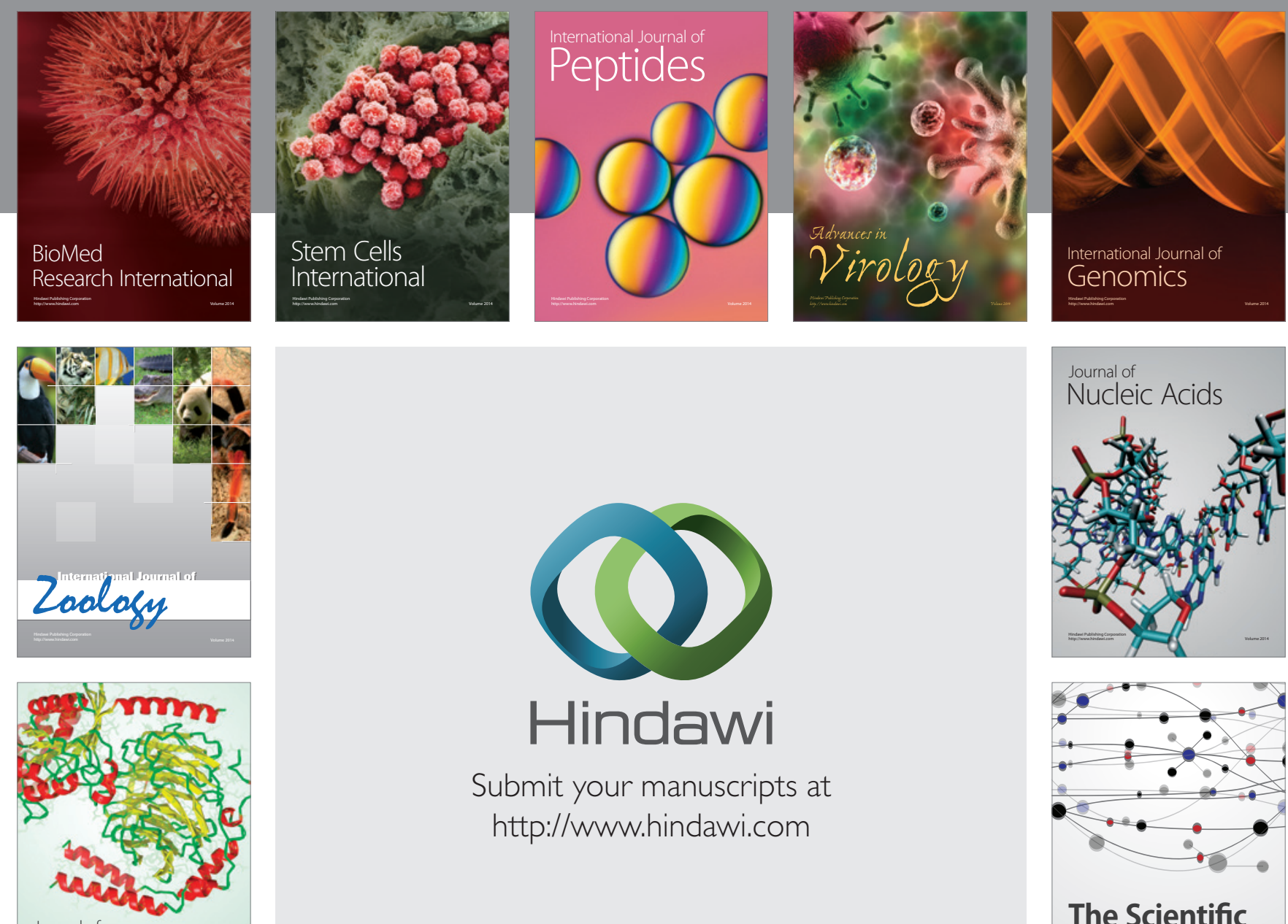

Submit your manuscripts at

http://www.hindawi.com

Journal of
Signal Transduction
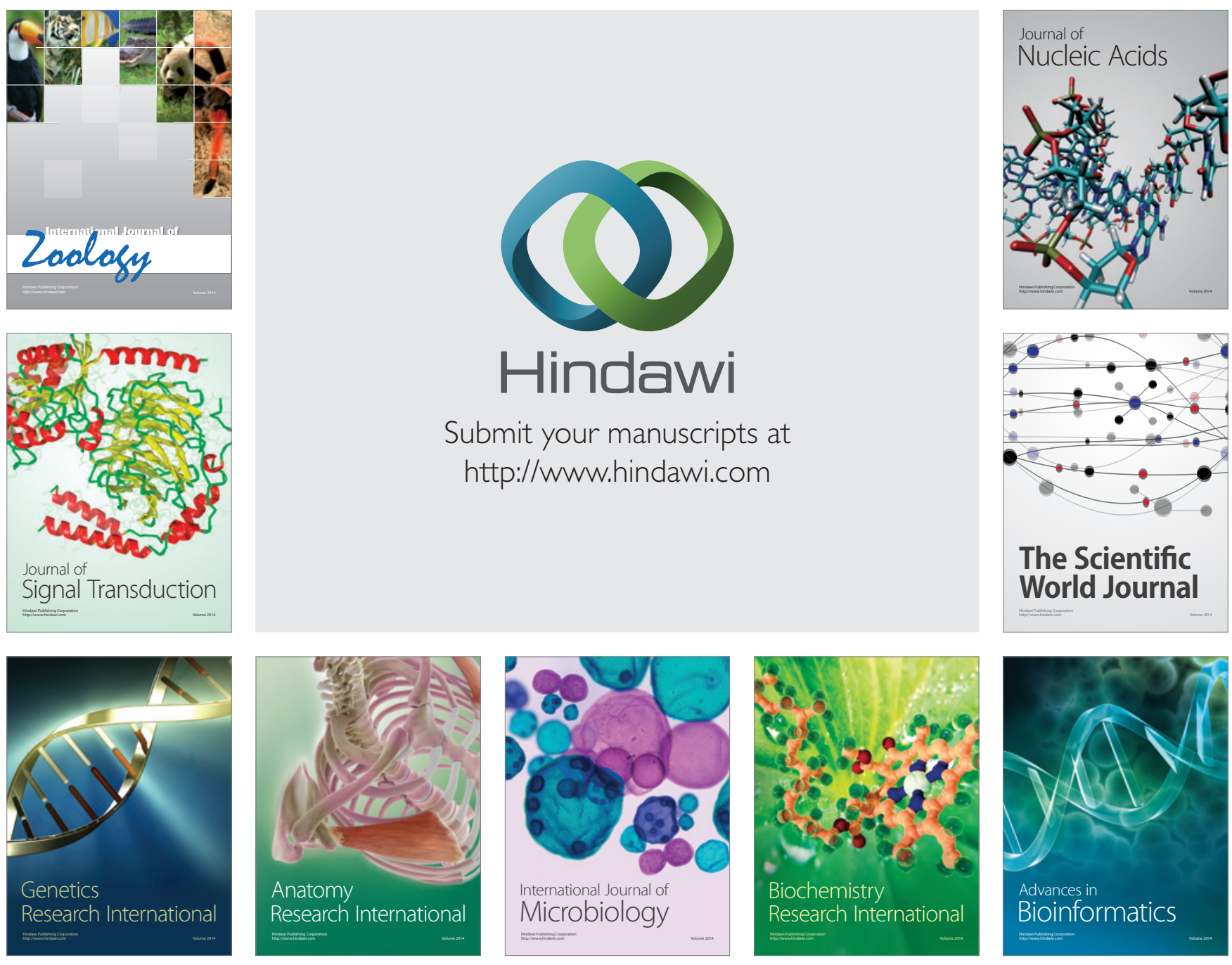

The Scientific World Journal
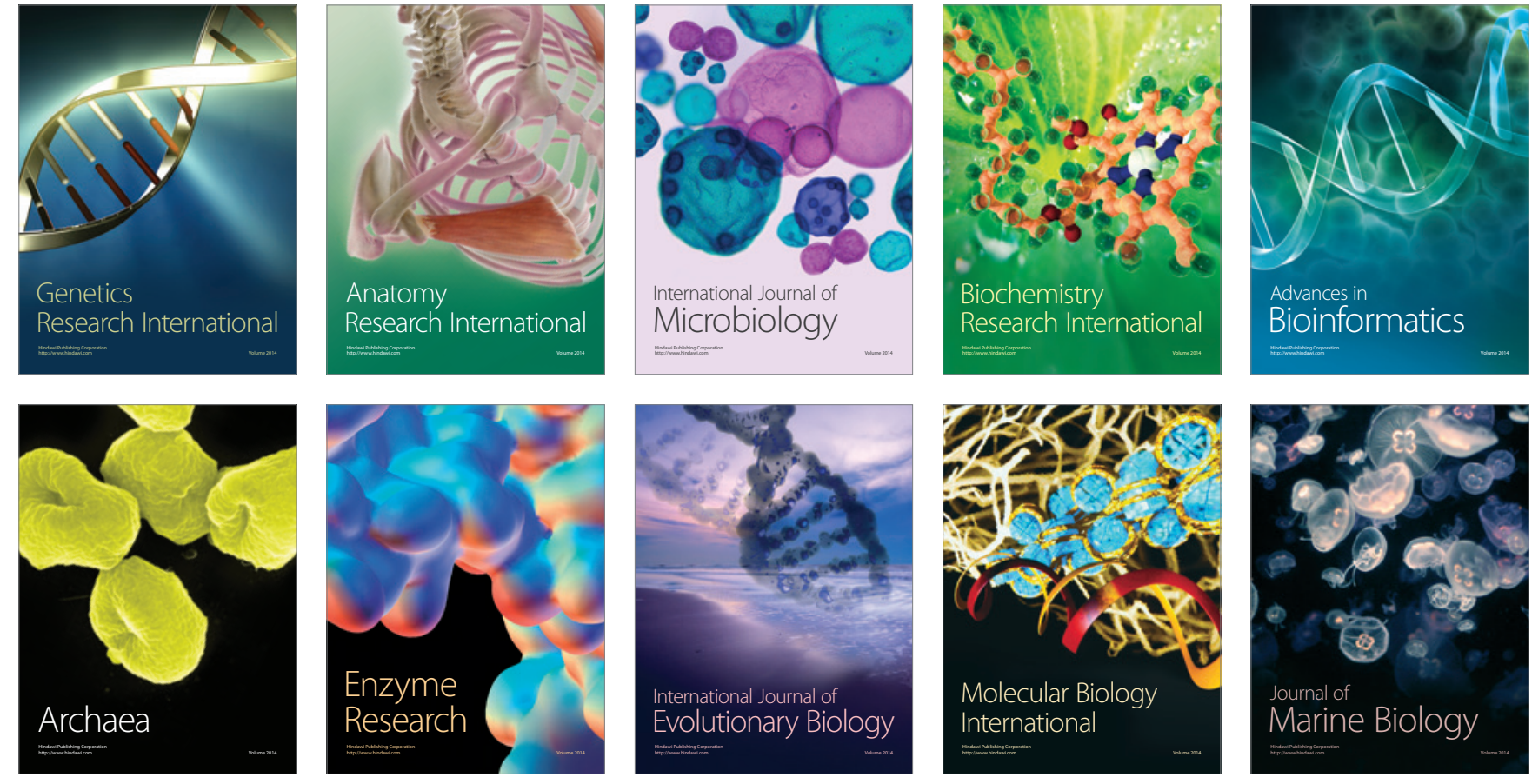